\title{
Occupational Accidents Footprint: New Concept Linked to Chain of Custody in Sustainable Forest Management
}

\section{HUELLA DE LA ACCIDENTALIDAD LABORAL: NUEVO CONCEPTO ASOCIADO A LA CADENA DE CUSTODIA EN MANEJO FORESTAL SUSTENTABLE}

Carlos G. Ackerknecht

Ingeniero Forestal, Experto Profesional en Prevención de Riesgos, Máster en Gestión Integrada de Prevención, Medio Ambiente y Calidad. Escuela de Salud Pública Universidad de Chile, Santiago de Chile.

\begin{abstract}
The study, due to inconveniences in previous methods, proposes the new concept of "occupational accidents footprint", and its implementation and traceability in the chain of custody $(\mathrm{CoC})$ related with sustainable forest management (SFM), through specially elaborated labor accident indicators.

Data from primary sources related to fatal cases, non fatal accidents and lost time on forest operations accidents of 24 countries, plus production associated to those works, was compiled; and then, processed to get results in terms of fatal cases/million m3, total work accidents/million $\mathrm{m} 3$ and total lost time/million $\mathrm{m} 3$.

Results show that is feasible to apply the concept of occupational accidents footprint to measure aggregated value to forest products certification of the CoC. In Production vs Fatality the cleanest occupational accidents footprint in the forests belongs to Germany, Belgium, Finland and Australia; for Production vs Accidents the best behaviors are for Sweden, USA, New Zealand and Belgium; while in Production vs Lost Time Finland, Belgium and Austria are leaders. Due to the convenience to make evident the labor accidents impact on forest products aggregated value, it is proposed the implementation of new safety indicators associated to the occupational accidents footprint, in order to be useful in the certification of CoC in SFM.
\end{abstract}

Key words: FOOTPRINT, SUSTAINABLE FOREST MANAGEMENT, WORK FATALITIES, WORK ACCIDENTS, LOST TIME ACCIDENTS.

\section{INTRODUCTION}

In technical and scientific terminology there are various types of footprints. First, we have the human footprint developed by researchers from Wildlife Conservation Society Institute and the

Correspondencia / Correspondence:

e-mail: carlos.ackerknecht@gmail.com

Recibido: 31 de julio 2014 / Aceptado: 22 de septiembre 2014

\section{RESUMEN}

El estudio, debido a inconveniencias en métodos previos, propone el nuevo concepto de "huella de accidentalidad laboral", y su implementación y trazabilidad en la cadena de custodia (CdC) en manejo forestal sustentable (MFS), mediante indicadores de accidentalidad ocupacional especiales.

Se recolectaron datos de fuentes primarias sobre casos fatales, accidentes no fatales y tiempo perdido en siniestros ocurridos en operaciones forestales de 24 países, más producción asociadas a dichas faenas, siendo éstos procesados para obtener resultados de casos fatales/millón m3, cantidad accidentes/millón m3 y tiempo perdido/ millón m3.

Los resultados evidencian la factibilidad de aplicar el concepto de huella de accidentalidad laboral para medir agregación de valor a productos forestales en la CdC. En Producción vs Fatalidad la huella de accidentalidad laboral más limpia en bosques corresponde a Alemania, Bélgica, Finlandia y Australia; para Producción vs Accidentes los mejores comportamiento son de Suecia, EE.UU., Nueva Zelandia y Bélgica; mientras que en Producción vs Tiempo Perdido se destacan Finlandia, Bélgica y Austria.

Siendo conveniente transparentar en los productos forestales el impacto de los accidentes del trabajo en su agregación de valor, se propone establecer indicadores asociados a la huella de accidentalidad laboral útiles en la certificación de la CdC en MFS.

(Ackerknecht C, 2014. Occupational Accidents Footprint: New Concept Linked to Chain of Custody in Sustainable Forest Management. Cienc Trab. Sep-Dic; 16 [51]: 131-136).

Palabras clave: HUELLA, MANEJO FORESTAL SUSTENTABLE, FATALIDADES LABORALES, ACCIDENTES DEL TRABAJO, TIEMPO PERDIDO POR ACCIDENTES.
Center for International Earth Science Information Network (University of Columbia) ${ }^{1}$ The human footprint is defined as a global map of the human influence on Earth surface, mainly on terms of natural state loss ${ }^{1}$ or human domestication of the planet ${ }^{2}$ According to Mendoza ${ }^{3}$, the human footprint calculation is made by measuring the ecological trail based on two areas: the cover to produce resources required by a community (farming, grasses and forests, inter alia) and the additional surface to dispose garbage, wastewater and other residues. In other words, the measuring reveals the Earth's load capacity, populations lifestyles, impact caused on territory and sustainable degree of the environment. On the other hand, professor Arjen Hoekstra from UNESCO-IHE presented the water footprint concept ${ }^{4}$, as an alternative indicator for water use, which is defined as fresh water total volume used to 
produce goods and services delivered by a company, or consumed by an individual or a community. This water use is measured in terms of volumes for consumed, evaporated or polluted water, either per unit time for individuals and communities, or by mass unit for enterprises.

Meanwhile, in recent decades the carbon footprint has become the most notorious and widespread human trail, created under the leadership of Jean-Marc Jancovici. According to the Chilean Ministry of Environment ${ }^{5}$ the carbon footprint is defined as the overall emissions of greenhouse gases produced, directly or indirectly, by persons, organizations, products, events or geographic regions in terms of $\mathrm{CO} 2$ equivalents, and serves as a useful management tool for behaviors or actions that are helping to increase our emissions, how we can improve and make more efficient use of resources. This footprint is born as a measure to quantify and generate an indicator of the impact that an activity or process is about, beyond climate change the big emitters. The carbon footprint is measured by mass (g, $\mathrm{kg}$ or ton) of $\mathrm{CO} 2$ equivalent (CO2 and/or C02eq).

Most countries have signed the Convention No. 187 of ILO promotional framework for occupational health and safety (OHS) and they agree to implement a national policy of risk prevention with systems and programs to prevent occupational accidents and professional diseases in their nations, all of which requires generating a series of indicators and verifiers that are quantifiable and measurable. ${ }^{6}$

In creating safer and healthier workplaces have certainly contributed the codes of good forestry practices promoted in various countries. Along with this, has also contributed to OHS improvements in the woods the implementation of sustainable forest management (SFM) models. As an example, the FSC (Forest Stewardship Council) and PEFC (Program for the Endorsement of Forest Certification), which in its principles and criteria require to observe risk prevention regulations for the benefit of workers:

\section{FSC:}

Criterion 4.2. Forest management should meet or exceed all applicable laws and/or regulations covering health and safety of employees and their families ${ }^{7,8}$.

\section{PEFC National Standard of Forest Certification for Chile (CERTFOR):}

Criterion 5.1. There is a reasonable evidence that during the process the organization complies with legal requirements related to health, work and safety ${ }^{9,10}$.

The certification of the chain of custody $(\mathrm{CoC})$ tracks raw materials from certified forests to ensure sustainability (woods of controlled origin) to the final consumer, through industrial processes and checking that customers are buying a product from responsibly managed forest (otherwise expressed, honestly cared forests from the social perspective and in harmony with the environment). According to CERTFOR ${ }^{9}$, the CoC of forest products is the process management of information about the category of raw material for forest products, enabling the organization to make accurate and verifiable statements about the content of certified raw material. As per De Benedetto and Klemeš ${ }^{11,12}$. the Life Cycle Assessment (LCA; defined by IS014040:2006, as the compilation and evaluation of the inputs, outputs and the potential environmental impacts of a product system throughout its life cycle) is a well- known tool for analyzing environmental impacts on a wide perspective with reference to a product system and the related environmental and economic impacts. For example, through an Environmental Performance Strategy Map (EPSM), LCA has a potential to evaluate various footprints such as carbon footprint, water footprint, energy footprint, emissions footprint, work environment footprint and others. To build the EPSM, the work environment LCA includes categories, such as, fatal accidents, total number of accidents, central nervous system function disorders, hearing damages, cancer, muscle-skeletal disorders, airways diseases, skin diseases and psycho-social diseases ${ }^{13}$. This footprint unit of measure is the number of lost days of work/person.

Unfortunately, LCA has limitations when a sector assessment needs to increase the level of detail beyond the level allowed by the basic statistical information ${ }^{13}$. For example, same authors experienced difficulties to provide proper results while assessing LCA in forestry operations. Forest work is characterized by its seasonability: in the majority of companies most are not permanent ${ }^{14}$ and then, forestry and logging operations are generally short term works. Also, since forestry and logging operations take place in open and variable environmental scenarios, that do not allow stable work conditions, is quite difficult to find clear comparative items like within fixed industrial workplaces.

On the other hand, is not easy to make a clear difference between common and professional diseases criteria used to assess LCA. Since work accidents has an exact date of occurrence; but, while qualifying an occupational illness the starting day is not very precise (with difficulties to count and to mark lost time on a specific forest product or service), in terms of OHS only accidents at work should be valid to be considered for LCA impact categories. Thence, a new work environment footprint with different occupational safety impact categories should be implemented for forestry and logging operations.

Assimilating these principles to creation and implementation of the occupational accidents footprint, has said that the Convention No. 187 involves the desirability of establishing new standards, criteria, indicators and verifiers that are quantifiable and measurable (Frequency Rate, Severity Rate and Fatalities Rate, among others, which are not easily comparable indicators between countries).

To this end, an innovative approach to preventive issues related to the certification of the CoC integrated with LCA tools, in order to create more aggregated value to forest business, intends to apply explicit indicators and verifiers to SFM standards to mark accidents directly, and also, underpins the traceability of forest products and services. Some examples for fatal cases related to logging production are provided by Klun and Medved ${ }^{15}$ and Cabeças ${ }^{16}$, both cited by Albizu-Urionabarrenetxea, P. et al. ${ }^{14}$

The methodology developed in this study to implement the occupational accidents footprint concept will be described below, and also results and their corresponding analysis, to finally deliver some conclusions and recommendations.

\section{MATERIAL AND METHODS}

The technical information collected from countries on behalf the research was requested based on the following antecedents:

Classification of economic activities ${ }^{17}$ :

- 0210: Silviculture and other forestry activities.

- 0220: Logging. 
Occupational safety statistics data for each economic activity:

- Total accumulated non fatal accidents for each year.

- Total fatal cases per year.

- Total accumulated lost time due to work accidents for each year.

- Annual production for each economic activity (million cubic meters harvested).

- Criteria used to define work accidents and their lost time for each country.

Years: 2010, 2011 and 2012.

In fact, 61 specialized organizations (ILO, FAO, universities, OHS mutualities, ministries plus research \& development institutes and companies) from 24 countries were consulted, representing a universe of technical information exchange with 74 directors, managers, academicians, researchers and technical staff in North America, Europe, Oceania and Latin America related to OHS. The information request was included in a form (available in Spanish and English; see the second one at Appendix), which was distributed via email to contacts being monitored their responses and consequent clarification of data, calculations and subsequent criteria by the same route with an average of 3 messages exchanged by participating OHS specialist.

In receiving answers a marked tendency for countries was to maintain official accidents statistics only for Agriculture, Forestry and Fisheries as joint activity. Accordingly, any information about specific forest products activity was investigated specifically by our contacts on behalf of the study.

Furthermore, given the great diversity of ways to register and calculate statistical information among countries (some nations begin accident record from the day of occurrence of the accident itself; countries in the European Union included only accidents with more than 3 days lost time), were to implement allocation criteria for standardizing information and make it comparable to preventive reality among nations. The main agreements set arbitrarily and based on previous experiences, were:

- Merge items 0210 and 0220 to obtain a single value for activities in the forest.

- Percentage of lost-time accidents: 1 day (7.5\%), 2 days (22.5\%) and 3 days (30.0\%).

Given the desirability of new, more direct and feasible indicators to compare different preventive realities in forest operations between countries, as well as the convenience to mark an evidence of the impact of the accident on the products to keep for traceability processes in the $\mathrm{CoC}$ (occupational accidents footprint), data receipt from primary sources was assimilated to calculate the following indicators of OHS associated with forest production:

Production vs Fatality $(\mathrm{P} / \mathrm{F})=\frac{\text { Total Fatal Cases }}{\text { Million Cubic Meters Harvested }}$

Production vs Total Non Fatal Accidents

Accidents (P/A) Million Cubic Meters Harvested

Production vs $=$ Total Lost Days from Accidents

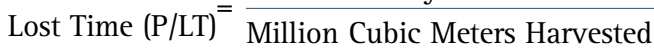

The resulting information was ordered according to these indicators $(\mathrm{P} / \mathrm{F}, \mathrm{P} / \mathrm{A}$ and $\mathrm{P} / \mathrm{LT})$, separating different tables in the comparative results of countries with claims from one or more days lost and those who do from the day number 4. Any information that failed to properly clear was discarded, leaving out data from some countries (e.g., statistics from certain countries were incomplete, unclear or inadequate).

Finally, the information within the tables was ordered by hierarchy, establishing a ranking of performance among countries participating in the study.

\section{RESULTS}

The surveys sent to 74 OHS specialists from 24 countries in North America, Europe, Oceania and Latin America had a response of $50.8 \%$ of managers, academicians, researchers and technical staff consulted.

The following tables present the results obtained in the study ordered by economic activity and occupational safety indicator, segregating as record start considering the lost time and the average values obtained from the years of the study (2010, 2011 and 2012).

Production v/s fatalities: Fatal cases/million m3 (P/F): Germany and Belgium, because they lack of fatalities in their forests, have a clean production in timber harvested between 2010 and 2012. Followers with accident footprints slightly marked are Finland, Australia and Sweden. Chile ranks No.9, surpassing the USA, UK, Austria and Italy (Table 1).

Table 1.

Production v/s fatalities in forest operations by country (fatal cases per million cubic meters harvested).

$\begin{array}{lcc}\text { COUNTRY } & \begin{array}{c}\text { Fatal Cases/Million M3 } \\ (2010-2012 \text { Average) }\end{array} & \begin{array}{c}\text { Source } \\ (*)\end{array} \\ \text { Germany } & 0 & \mathrm{BMAS}^{18} / \mathrm{FAO}^{19} \\ \text { Belgium } & 0 & \mathrm{FOA}^{20} / \mathrm{EU}^{2} \mathrm{OSHA}^{21} / \mathrm{FAO}^{19} \\ \text { Finland } & 0.0064 & \mathrm{TL}^{22} / \mathrm{TUT}^{23} / \mathrm{FAII}^{24} \\ \text { Australia } & 0.01 & \mathrm{NZFOA}^{25} \\ \text { Sweden } & 0.04 & \mathrm{SWEA}^{26 /} \mathrm{FAO}^{19} \\ \text { New Zealand } & 0.16 & \mathrm{NZFO}^{25} \\ \text { Canada (Province of BC) } & 0.17 & \mathrm{NZFOA}^{25} \\ \text { Spain } & 0.18 & \mathrm{MEYSS}^{27} / \mathrm{FAO}^{19} \\ \text { Chile } & 0.21 & \mathrm{ACHS}^{28} / \mathrm{NFOR}^{29} \\ \text { USA } & 0.22 & \mathrm{NIOSH}^{30} / \mathrm{BLS}^{31} / \mathrm{FAO}^{19} \\ \text { United Kingdom } & 0.23 & \mathrm{NZFOA}^{25} \\ \text { Austria } & 0.30 & \mathrm{AUVA}^{32} / \mathrm{FAO}^{19} \\ \text { Italy } & 2.05 & \mathrm{INAIL}^{33} / \mathrm{FAO}^{19}\end{array}$

(*) Data elaborated by author using information provided by sources.

Production v/s accidents: Total non fatal accidents with lost time/million m3 (P/A): Sweden has the lowest impact on labor accidents footprint (according to number of accidents/million $\mathrm{m} 3$ harvested in forests). Next are USA, New Zealand, Belgium, Finland, Australia, UK and Austria, which are located before Chile (No. 9) (Table 2).

Production v/s lost time: Total days lost/million m3 (P/LT): Finland has the lowest footprint for days lost because of labor accidents per million $\mathrm{m} 3$ harvested in forests. Followers are Belgium (nearly tripling Finland) and Austria (almost five times than the first position). The ranking ends with Chile (around six time than Finland) (Table 3). 
Table 2.

Production v/s non fatal accidents in forest operations by country (with 1 and 4 or more days of lost time per million cubic meters harvested).

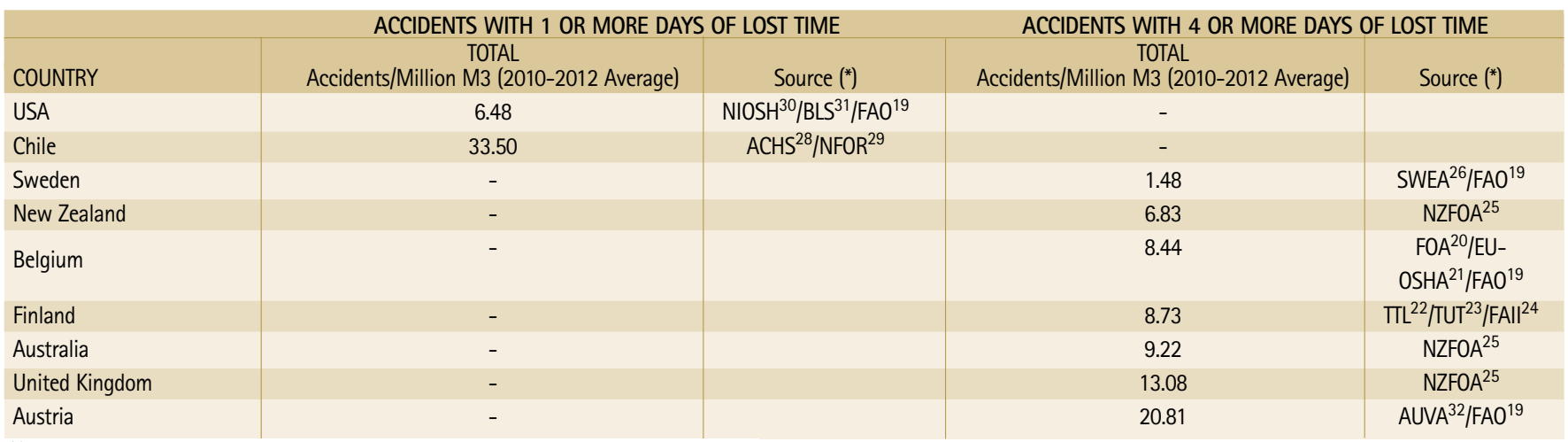

(*) Data elaborated by author using information provided by sources.

Table 3.

Production v/s lost time in forest operations by country (with 1 and 4 or more days of lost time per million cubic meters harvested).

\begin{tabular}{|c|c|c|c|c|}
\hline \multicolumn{3}{|c|}{ ACCIDENTS WITH 1 OR MORE DAYS OF LOST TIME } & \multicolumn{2}{|c|}{ ACCIDENTS WITH 4 OR MORE DAYS OF LOST TIME } \\
\hline Chile & 909.02 & $\mathrm{ACHS}^{28} / \mathrm{INFOR}^{29}$ & - & \\
\hline Belgium & - & & 395.18 & FOA $^{20} /$ EU-OSHA $^{21} /$ FAO $^{19}$ \\
\hline Austria & - & & 770.96 & $\mathrm{AUVA}^{32} / \mathrm{FAO}^{19}$ \\
\hline
\end{tabular}

(*) Data elaborated by author using information provided by sources.

\section{DISCUSSION}

In terms of OHS, a new edge to align with the compliance of ILO Convention No. 187 is to demonstrate the commitment of everyone involved in the CoC of forest products for their policies, management systems and programs implemented on risk prevention. In other words, to make clear the concerns about leaving a mark on human respect matters.

As part of this, FSC established at an early stage that each organization would require to demonstrate this commitment with human aspects by signing a self-declaration, establishing its commitment to the values of the corresponding SFM standards, and develop as well as maintain procedures OHS in the work environment established under the framework of certification in the $\mathrm{CoC}$ (failure to do so would generate a minor non-conformity or greater, depending on the severity). At a later stage, other auditable OHS evidences previously established under indicators are required by the standards and based on experiences and feedback collected from stakeholders.

In turn, CERTFOR delivers a wide range of explicit indicators and verifiers that allow to fully meet criteria for OHS, which ensure they reach at least the minimum legal requirements applicable to the activity. This allows to test a well-bounded approach to compliance with regulations, approaching the measurement of the occupational accident footprint in the sections of the CoC standard related to forest operations in the country.

New indicators provided by the study, besides to establish international comparisons between countries and forestry companies, show a more logical and obvious association of accidents with production, which facilitates the aggregation or decrease of the resulting value to forest products, such as to offer market wood without accidents involved, ie, logs with a zero labor accidents footprint. The precise occupational safety implications of the new categories provides a stronger social and economic impact to forestry and logging operations, besides of to facilitate the traceability of accidents and its associated lost time, which are not duly reflected in previous work environment footprint assessment methods.

Also facilitate to emphasize the favorable evolution in time of accidents or lost time reductions. All these actions should be considered in the monitoring and control during the process of certification of the entire $\mathrm{CoC}$ associated with forest products.

In the study period and sample, Scandinavian countries show the cleanest occupational accidents footprint in its forests, and also, some European, result which agrees with previous researches from other authors. Oceanic, North American and Chilean forests are marked with more labor accidents than in Scandinavia and Europe.

There are no doubts that the mark set by the good performance of companies in human matters, especially with regard to safety at work duly certified as elements of the occupational accident footprint, broadly encourages greater acceptance of our forest products and services in international markets.

\section{CONCLUSIONS}

Proactive implementation of the concept of occupational accident footprint will be a significant contribution to promote the creation and strong maintenance of safer and healthier workplaces in forestry and logging operations around the world, and also, an excellent contribution to aggregate value to forests.

Consequently, the occupational accidents footprint for forest and logging operations is defined as a measure of the total amount of fatal cases at work, labor non fatal accidents and their corresponding lost time associated to million cubic meters of harvested wood in forest operations. 
With regard to the desirability of transparency in the impact of accidents on adding value to forest products, is proposed to establish indicators for occupational accidents footprint: fatal cases/million $\mathrm{m} 3$, non fatal accidents/million $\mathrm{m} 3$ and lost time/million $\mathrm{m} 3$.

Scandinavian countries have the cleanest occupational accidents footprint in its forests, and also, some European. Oceanic, North American and Chilean forests are marked with more labor accidents. Finally, the mark set by the good performance of companies in human subjects, especially with regard to OHS through occupational accidents footprint, encourages greater acceptance of forest products and services in worldwide markets.

\section{Acknowledgments}

Our best words of appreciation to the numerous OHS specialists and organizations that gently provided valuable information on behalf of this research (by alphabetical order): ACHS (P.Vargas, C.Morales), AUVA (B.Mayer), BLS (J.Ruser), BMAS (R.Gerber), EU-OSHA (S.Bristow, F.Dehasque, M.Häckel-Bucher, B.KöhlerKrantz, R.Olsen, G.Olsvold, B.Pérez-Aznar, E.Rotoli, H.Schrama, M. van der Zwaan), FAII, FA0 (H.Ortiz), FOA (G.Mackie), ILO (P.Bustos, H.Nguyen), INAIL (A.Leva), INFOR (V.Alvarez), MEYSS, NIOSH (M.Fingerhut, S.Soderholm, J.Sestito, T.Pizatella, J.Myers), NZFOA, SWEA (A.Althen, K.Blom), TTL (K.Ojanen), TUT (K. Saarela, N.Nenonen) and U de Chile (P.Frenz, N.Marchetti and K.Rivas).

\section{Abbreviations}

ACHS : Asociación Chilena de Seguridad/Chilean Safety Association.

AUVA : Allgemeine Unfallversicherungsanstalt/General Accident Insurance Company.

BLS : Bureau of Labor Statistics, U.S. Department of Labor.

BMAS : Bundesministerium für Arbeit und Sociales/Federal Ministry of Labor and Social Affairs.

CERTFOR: PEFC National Standard of Forest Certification for Chile.

EU-OSHA: European Agency for Work and Health at Work.

FAII : Federation of Accident Insurance Institutions.

FAO : Food and Agriculture Organization.

FOA : Fund for Occupational Accidents.

FSC : Forest Stewardship Council.

ILO : International Labor Organization.

INAIL : Istituto Nazionale per L'Assicurazione contro gli Infortuni di Lavoro /National Institute for Work Accidents Insurance.

INFOR : Instituto Forestal/Forest Institute.

MEYSS : Ministerio de Empleo y Seguridad Social/Ministry of Employment and Social Security.

NIOSH : U.S. National Institute of Occupational Safety and Health.

NZFOA : New Zealand Forest Owners Association.

OHS : Occupational Health and Safety.

PEFC : Program for the Endorsement of Forest Certification.

SWEA : Swedish Work Environment Authority.

TTL : Työterveyslaitos/Finnish Institute of Occupational Health.

TUT : Tampere University of Technology.

UNESCO-IHE: United Nations Educational, Scientific and Cultural Organization-Institute for Water Education.

\section{APPENDIX.}

Information request form (English version).

\section{OCCUPATIONAL SAFETY DATA RESEARCH}

The University of Chile is conducting an international comparative research on occupational safety related to forestry \& logging operations.

The main objective of this study is to compare frequency rate, accidents rates and other safety statistical data for the last 3 years in forestry \& logging operations in different countries.

We honestly appreciate your help in order to provide us the proper information from your country requested on this form. In case of rates or indicators, please provide us with formulas and criteria to calculate them (specially, definition for work accidents and when their lost time is initiated).

The collected data will be used and kept under the confidentiality and restrictions requested by providers (no specific organization name will be released; companies identification will be replaced by code numbers).

We honestly appreciate your cooperation.

Prof. Carlos G. Ackerknecht, MGI, RPF (Ret.)

\section{Information level (name of the country, state, province, region or company):}

In case of a company, please provide the location information (city, state and country
Economic activity $\left(^{*}\right.$ ): 0210 (Silviculture and other Forestry Activities).
ITEM
Total accidents (per year)
Total lost time (days per year)
Workers average (year)
Total worked hours (year)
Frequency rate (1 million hours)
Total fatal cases (year)
Production (cubic meters/year)

Comments: Please specify type of forest management activities involved (tree orchards, nurseries, planting, spacing, thinning, pesticides application, fertilization, forest firefighting or others).
Economic activity $\left({ }^{*}\right)$ : 0220 (Logging).

ITEM
Total accidents (per year)
Total lost time (days per year)
Workers average (year)
Total worked hours (year)
Frequency rate (1 million hours)
Total fatal cases (year)
Production (cubic meters harvested/year)

Comments: Please specify type of logging operations (ground skidding, logging towers, harvester/forwarder or others).

(*) According to ISIC (International Standard Industrial Classification for All Economic Activities) of United Nations, Rev. 4, 2008. 
1. Sanderson, E.C. Jaiteh, M. Levy, M.A. Redford, K.H. Vannebo, A.V. and Woolmer, G. The human footprint and the last of the wild. Bioscience. 2002; 52(10): 891-904.

2. Kareiva, P. Watts, S. McDonald, R. and Boucher, T. Domesticated nature: Shaping landscapes and ecosystems for human welfare. Science. 2007; 316(5833): 1866-1869.

3. Mendoza, A. 2014. Planeta Tierra; La huella humana. Available in http:// www.sogeocol.edu.co/Pildoras/nota138.htm [13 May 2014] [In Spanish]

4. Hoekstra, A.Y. Virtual water trade: Proceedings of the International Expert Meeting on Virtual Water Trade. IHE Delft. The Netherlands. 2003. Available in http://www.waterfootprint.org/Reports/Report12.pdf [12 May 2014]

5. Ministerio del Medio Ambiente de Chile. Huella de carbono. 2014 Available in http://www.mma.gob.cl/1304/w3-article-54747.html [12 May 2014]

6. Organización Internacional del Trabajo (ILO). Convenio 187 sobre el marco promocional para la seguridad y salud en el trabajo. 2006 Available in http:// www.ilo.org/dyn/normlex/es/f?p=NORMLEXPUB:12100:0::NO:: P12100_IL_ CODE:C187 [13 May 2014] [In Spanish]

7. Forest Stewardship Council. FSC principles and criteria for forest stewardship. FSC-STD-01-001 VA-0 EN. 2013: p 13. Available in http://www.cl.fsc. org/fileadmin/fsc_chile/page_content/pdf/FSC_STD_01_001_V4_0_EN_ FSC_Principles_and_Criteria.pdf [13 May 2014] [In Spanish]

8. Forest Stewardship Council. 2011. Evaluation of the organization's commitment to FSC values and occupational health and safety in the Chain of Custody. FSC-PRO-20-001 V1-0 2011.

9. CERTFOR. Estándar CERTFOR de cadena de custodia. DN-02-07. 362013 Available in http://www.certfor.org/userfiles/file/CERTFOR\%20DOCUMENTOS/DN02-07\%20Est $\%$ C3\% A1ndar\%20CdC\%20CERTFOR\%20\%28Versi $\%$ C3\%B3 n\%202007\%20-\%20Enmienda\%202013\%29.pdf [13 May 2014] [In Spanish]

10. PEFC Council. Chain of Custody of Forest Based Products-Requirements. PEFC ST 2002:2010. 2010: $33 \mathrm{p}$.

11. De Benedetto, L. and Klemeš, J. The Environmental Performance Strategy Map: an integrated LCA approach to support the strategic decision-making process. Journal of Cleaner Production. 2009; 17(10): 900-906.

12. Klemeš, J. and De Benedetto, L. Environmental Assessment and Strategic Environmental Map Based on Footprints Assessment. In Treatise on Sustainability Science and Engineering. Springer Netherlands.2013: 153-171

13. Schmidt $A$, Poulsen PB, Andreasen J, Floee T, Poulsen KE. The working environment in LCA. A new approach. In: Guidelines from the Danish Environmental Agency. Danish Ministry of Environment. 2004; 72. Available at: http://www. Ica-center.dk/resources/779.pdf [20 September 2014].

14. Albizu-Urionabarrenetxea, P. et al. Safety and health in forest harvesting operations. Diagnosis and preventive actions. A review. Forest Systems. 2013; 22(3): 392-400
15. Klun, J. and Medved, M. Fatal accidents in forestry in some European countries. Croat J ForEng. 2007; 28(1): 55-62.

16. Cabeças, J. An approach to health and safety in E.U. forestry operations Hazards and preventive measures. Enterprise and Work Innovation Studies, 2007; 3: 19-31.

17. United Nations. International Standard Industrial Classification of All Economic Activities (ISIC). Department of Economic and Social Affairs, Statistics Division. New York. 2008; Serie M 4 (4): 306 p.

18. Bundesministerium für Arbeit und Sociales (BMAS). Written communications (emails) [12 and 17 September 2013] [In English].

19. Food and Agriculture Organization (FAO). Estado de los Bosques del Mundo. 10 edición española. Roma. 2012: 168 p. [In Spanish].

20. Fund for Occupational Accidents (FOA). Written communication (email) [28 August 2013] [In English].

21. European Agency for Work and Health at Work (EU-OSHA). Written communication (email) [18 September 2013] [In English].

22. Työterveyslaitos (TL). Written communications (emails) [26 September 2013 and 30 October 2013] [In English].

23. Tampere University of Technology (TUT). Written communications (emails) $[2,7$ and 28 October 2013] [In English].

24. Federation of Accident Insurance Institutions (FAll). Written communications (emails) [2 and 7 October 2013] [In English].

25. New Zealand Forest Owners Association (NZFOA). Written communication (email) [28 August 2013] [In English].

26. Swedish Work Environment Authority (SWEA). Written communications (emails) [24 and 26 September 2013] [In English].

27. Ministerio de Empleo y Seguridad Social (MEYSS). Written communications (emails) [11 and 17 September 2013; 24 and 30 October 2013; and 14 November 2013] [In Spanish].

28. Asociación Chilena de Seguridad (ACHS). Written communication (email) [5 September 2013] [In Spanish].

29. Instituto Forestal (INFOR). Written communications (emails) [12 September 2013; 15 and 20 October 2013] [In Spanish].

30. U.S. National Institute of Occupational Safety and Health (NIOSH). Written communications (emails) [4 October 2013 and 18 October 2013] [In English].

31. Bureau of Labor Statistics, U.S. Department of Labor (BLS). Written communication (email) [27 August 2013] [In English].

32. Allgemeine Unfallversicherungsanstalt (AUVA). Written communication (email) [21 October 2013] [In English].

33. Istituto Nazionale per L'Assicurazione contro gli Infortuni di Lavoro (INAIL). Written communications (emails) [20 September 2013 and 18 October 2013] [In English]. 